\title{
METODE SIMULASI BERBASIS PROJECT BASED LEARNING SEBAGAI ALTERNATIF UPAYA MENINGKATKAN MOTIVASI DAN HASIL BELAJAR KONSEP MUTASI PADA SISWA KELAS XII MIPA SMA NEGERI 1 MOGA TAHUN PELAJARAN 2019/2020
}

(Simulation Method Based on Project Based Learning as an Alternative Effort to Improve Motivation and Result of Learning Mutation Concept in Class XII MIPA SMA Negeri 1

Moga Academic Year 2019/2020)

\author{
Oleh: Masruri*) \\ E-mail :masruri@gmail.com
}

${ }^{*}$ SMA Negeri 1 Moga Pemalang Jawa Tengah

\begin{abstract}
Research aims to determine the increased motivation of learning and learning outcomes of biological mutation concepts in the students of Grade XII MIPA SMA Negeri 1 Moga through the implementation of simulation methods based on projectlearning, as well as the constraints experienced in the learning process. The instrument used consists of a poll to learn the student's motivation, and the multiple choice tests (pre-test and post-test) are selected to know the student's learning outcomes. The Data in this study was analyzed qualitatively and quantatatives. Qualitative analysis is conducted to determine the motivation for learning, while quantitative analysis is used to determine the improvement of student learning outcomes in the mutation concept. After the authors process the learning using a project Based learning simulation method in class XII MIPA3 SMAN 1 Moga Academic Year 2019/2020 there is an increase in learning motivation and student learning outcomes. Through this learning activity students can calculate.
\end{abstract}

Keywords: Simulation methods, Project Based Learning, Motivation, Learning outcomes, Mutation

\section{PENDAHULUAN}

Menurut Undang-Undang Sistem Pendidikan Nasional Nomor 20 Tahun 2003 pendidikan nasional berfungsi mengembangkan kemampuan dan membentuk watak serta peradaban bangsa yang bermartabat dalam rangka mencerdaskan kehidupan bangsa, bertujuan untuk berkembangnya potensi peserta didik agar menjadi manusia yang beriman dan bertakwa kepada Tuhan Yang Maha Esa, berakhlak mulia, sehat, berilmu, cakap, kreatif, mandiri, dan menjadi warganegara yang demokratis serta bertanggung jawab.

Proses pembelajaran yang baik meliputi mengajarkan bagaimana siswa itu belajar, bagaimana mengingat, bagaimana berfikir dan bagaimana memotivasi diri mereka sendiri dan interaksi aktif antara pendidik dan siswa (Meyer dalam Yeprina, 2019).

Guru dapat mengembangkan profesionalitasnya dalam mendidik. Penyampaian pembelajaran dengan metode pembelajaran yang variatif menjadi salah satu cara mengatasi kebosanan siswa dalam belajar. Hal ini dapat didukung dengan penggunaan media pembelajaran yang berkualitas. Misalnya, guru dapat menyajikan materi pembelajaran dengan memanfaatkan teknologi yang ada. Selain itu dengan berbagai metode-metode pembelajaran yang kreatif dan inovatif membuat para siswa tidak jenuh terhadap materi dan 
lebih berkembang. Memang, menjadi guru sebaiknya up to date dengan perkembangan zaman. Menjadi guru yang memiliki kemampuan teknologi baik akan mmembantu proses pembelajaran siswa. Dengan suasana tersebut, diharapkan dapat mengubah suasana kebosanan dalam belajar menjadi senang, lebih bergairah, dan termotivasi. Dengan demikian, prestasi siswa sangat berpotensi mengalami kenaikan (https://www.hipwee.com/).

Ketidakpahaman dan penguasaan siswa terhadap biologi disebabkan banyaknya konsep pada materi biologi, cara mengajar yang tidak tepat sasaran, kesulitan merepresentasi suatu fenomena, dan banyaknya istilah ilmiah. Dalam mempelajari biologi dibutuhkan kemampuan guru untuk meningkatkan pemahaman dan hasil belajar siswa (Rustaman, 2005). Untuk meningkatkan pemahaman dan hasil belajar siswa dapat dilakukan melalui pengembangan strategi, metode, pendekatan, model, dan media pembelajaran yang dapat menunjang proses kegiatan mengajar (Ulfa K, 2017).

Penggunaan metode yang tidak sesuai dengan tujuan pengajaran akan menjadi kendala dalam mencapai tujuan yang telah dirumuskan dalam kompetensi dasar. Cukup banyak bahan pelajaran yang terbuang percuma hanya karena penggunaan metode menurut kehendak guru dan mengabaikan kebutuhan siswa, fasilitas, serta situasi kelas (Djamarah \& Zein, 2010:87).

Salah satu metode dalam pembelajaran adalah metode simulasi. Metode ini dimaksudkan sebagai cara untuk menjelaskan sesuatu (bahan pelajaran) melalui perbuatan yang bersifat pura-pura atau melalui proses tingkah laku imitasi, atau bermain peran mengenai suatu tingkah laku yang dilakukan seolah-olah dalam keadaan yang sebenarnya (Sudjana, 2009).

Dalam penelitian ini metode simulasi yang diterapkan adalah metode simulasi dengan model pembelajaran project based learning. Melalui metode simulasi berbasis project based learning tersebut siswa diharapkan tidak hanya dapat melakukan simulasi langsung dalam menemukan pemahaman tentang konsep mutasi tetapi sebagai kegiatan pembelajaran tersebut siswa dapat menghasilkan suatu project berupa skenario materi simulasi dan dokumen berupa video pembelajaran mutasi yang mereka buat berdasarkan pemahaman yang diperoleh selama kegiatan belajarnya.

Pengertian metode simulasi menurut Anitah (2008:5.22) merupakan salah satu metode mengajar yang dapat digunakan dalam pembelajaran kelompok. Proses pembelajarannya objeknya cenderung bukan benda atau kegiatan yang sebenarnya, melainkan kegiatan mengajar yang sifatnya purapura. Selama proses pembelajaran, siswa dibina kemampuannya berkaitan dengan keterampilan berinteraksi dan berkomunikasi dalam kelompok. Selain itu, dalam metode simulasi siswa diajak untuk dapat bermain peran beberapa perilaku yang dianggap sesuai dengan tujuan pembelajaran. Sedangkan menurut Ruminiati (2007:2.6) metode simulasi adalah metode yang diberikan kepada siswa, agar siswa dapat menggunakan sekumpulan fakta, konsep, dan strategi tertentu (https://silabus.org/).

Penggunaan metode tersebut memberi kesempatan kepada siswa untuk berinteraksi sehingga dapat mengurangi rasa takut. Metode simulasi cenderung lebih dinamis dalam menanggapi gejala fisik dan sosial, karena melalui metode ini seolah-olah siswa melakukan hal-hal yang nyata ada. Dengan mensimulasikan sebuah kasus atau permasalahan, seseorang akan lebih menjiwai (https://silabus.org/).

Metode simulasi merupakan metode dimana siswa dilibatkan secara langsung dengan cara 
memerankan dan memperagakan suatu fungsi atau system dalam materi pembelajaran.Terlibatnya siswa dalam proses pembelajaran dan akan memberikan pengalaman secara langsung,sehingga siswa tidak akan melakukan aktivitas yang tidak berhubungan dengan pembelajaran. Selain itu keterlibatan siswa dalam pembelajaran akan menimbulkan perasaan senang karena dengan simulasi siswa secara tidak langsung melakukan kegiatan yang menyenangkan (Hariyanti, 2011).

Terdapat beberapa kelebihan dengan menggunakan metode simulasi sebagai , diantaranya:

1. Dapat dijadikan sebagai bekal bagi siswa dalam menghadapai situasi yang sebenarnya.

2. Dapat mengembangkan kreativitas siswa.

3. Dapat memupuk keberanian dan percaya diri siswa.

4. Memperkaya pengetahuan, sikap, dan keterampilan yang diperlukan dalam menghadapi berbagai situasi sosial yang problematis.

5. Dapat meningkatkan gairah siswa dalam proses pembelajaran (https://silabus.org/pengertianmetode/).

Model pembelajaran adalah kerangka konseptual yang melukiskan prosedur yang sistematis dalam mengorganisasikan pengalaman belajar untuk mencapai tujuan belajar tertentu dan berfungsi sebagai pedoman bagi para perancang pembelajaran dan para pengajar dalam merencanakan dan melaksanakan pembelajaran (Winataputra, 2001).

Project-Based Learning (PBL) adalah sebuah model atau pendekatan pembelajaran yang inovatif, yang menekankan belajar kontektual melalui kegiatankegiatan yang kompleks (CORD, 2001). Fokus pembelajaran terletak pada konsepkonsep dan prinsipprinsip inti dari suatu disiplin studi, melibatkan pebelajar dalam investigasi pemecahan masalah dan kegiatan tugastugas bermakna yang lain, memberi kesempatan pebelajar berkerja secara otonom mongkonstruksi pengetahuan mereka sendiri dan mencapai puncaknya menghasilkan produknya (Thomas, dalam Saidun 2010).

Model pembelajaran berbasis proyek dipilih karena model pembelajaran ini melibatkan para siswa dalam masalah-masalah kompleks, persoalan-persoalan di dunia nyata, dimana pun para siswa dapat memilih dan menentukan persoalan atau masalah yang bermakna bagi siswa. Selain itu, dalam pembelajaran berbasis proyek para siswa diharuskan menggunakan penyelidikan, penelitian keterampilan perencanaan, dan kemampuan pemecahan masalah saat siswa menyelesaikan proyek (Muliawati, dalam Indah Susilowati 2013).

Pembelajaran berbasis proyek juga menguntungkan dan efektif sebagai model pembelajaran. Melalui pembelajaran berbasis proyek, siswa menjadi terdorong lebih aktif dalam belajar, kreativitas siswa menjadi berkembang, guru hanya sebagai fasilitator, guru mengevaluasi produk hasil kinerja siswa dari proyek yang dikerjakan (Adnyawati, dalam Susilowati 2013).

Pembelajaran yang dilakukan dengan model pembelajaran berbasis proyek memiliki keuntungan sebagai berikut: meningkatkan motivasi, meningkatkan kemampuan pemecahan masalah, meningkatkan kolaborasi, meningkatkan ketrampilan mengelola sumber ( Saidun, 2010).

Berdasarkan Permen No 59 tahun 2014 lampiran Ic tentang Kurikulum SMA 2013 yang diterapkan di SMAN 1 Moga saat ini, mutasi termasuk dalam materi yang harus dipelajari pada kelas XII MIPA semester ganjil. Kompetensi Dasar (KD) 3.8. Menganalisis peristiwa mutasi pada makhluk hidup. 
Materi mutasi merupakan salah satu materi yang penting bagi peserta didik untuk dipahami. Pada implementasinya dalam pembelajaran, peserta didik tidak hanya dituntut utuk sekedar menghafal dan mengetahui konsep akan tetapi juga harus memahami dan dapat menjelaskan peristiwa mutasi yang terjadi dan pergeseran kerangka DNA yang dihasilkan akibat peristiwa mutasi. Menurut Saftri (2016: 190-192) ada beberapa hal penting di dalam konsep mutasi, yaitu:

1. Mutasi adalah perubahan yang terjadi pada bahan genetik (DNA atau RNA) baik pada taraf urutan gen maupun taraf kromosom.

2. Mutasi mempunyai syarat diantaranya terjadi perubahan materi genetik, yang bersifat dapat atau tidak dapat diperbaiki dan hasil perubahannya dapat diwariskan pada keturunannya.

3. Mutasi ada beberapa macam, berdasarkan proses terjadinya mutasi dibedakan menjadi dua yaitu mutasi alamiah dan buatan. Berdasarkan bagian tubuh yang mengalami mutasi, dibedakan menjadi mutasi somatis dan mutasi generatif. Berdasarkan bagian yang mengalami mutasi, dibagi dua yaitu mutasi gen dan mutasi kromosom (Mulyani,2017).

Penggunaan metode simulasi

berbasis project based learning diharapkan dapat meningkatkan motivasi belajar dan hasil belajar siswa. Pernyataan ini didukung oleh beberapa penelitian yang relevan. Hal ini sesuai dengan penelitian yang dilakukan oleh Hutasuhut (2010) bahwa dengan pembelajaran berbasis proyek dapat meningkatkan motivasi mahasiswa . Hal tersebut ditunjukkan dengan hasil peningkatan motivasi belajarnya dari 9.1\% menjadi $30.3 \%$ dan dalam kriteria sangat tinggi.

Berdasarkan

penelitian

Susilowati (2013), peningkatan hasil belajar pada kelas eksperimen lebih tinggi dibandingkan dengan kelas kontrol. Hasil uji N-Gain menunjukkan bahwa terdapat peningkatan antara sebelum diberikan perlakuan (pre-test) dengan sesudah diberikan perlakuan (post-test), dimana pada kelas eksperimen rata-rata peningkatan hasil belajarnya dalam kriteria tinggi yakni 0.71 dengan rincian persentase jumlah siswa dengan $\mathrm{N}$-Gain tinggi sebesar 53\% dan N-Gain sedang persentasenya sebesar 47\%. Pada kelas kontrol rata-rata peningkatan hasil belajarnya dalam kriteria sedang yakni 0.5 dengan rincian persentase jumlah siswa dengan N-Gain tinggi sebesar 7\%, N-Gain sedang sebesar $90 \%$ dan yang memperoleh $\mathrm{N}$ Gain rendah persentasenya sebesar 3\%.

Selanjutnya menurut hasil

penelitian Inyasiska (2015), pembelajaran project based learning dapat mempengaruhi motivasi belajar siswa lebih tinggi $14 \%$, kreativitas siswa meningkat $31,1 \%$, kemampuan berpikir kritis meningkat $34 \%$ dan melalui pembelajaran proyek yang bersifat kontekstual, kemampuan kognitif siswa juga meningkat $28,9 \%$ dari pada pembelajaran yang diberikan tanpa melalui proyek.

Berdasarkan latar belakang di atas, beberapa rumusan masalah dalam best practice ini yaitu:

1.Apakah penggunaan metode simulasi berbasis project based learning dapat meningkatkan motivasi belajar siswa pada konsep mutasi?

2. Apakah penggunaan metode simulasi berbasis project based learning dapat meningkatkan hasil belajar siswa pada konsep mutasi?

3. Kendala apa saja yang dialami dalam pembelajaran menggunakan metode simulasi berbasis project based learning?

\section{METODE PENELITIAN}

Populasi dalam penelitian ini adalah siswa kelas XII MIPA3 SMAN 1 Moga Tahun Pelajaran 2019/2020 dengan jumlah siswa 34 orang. 
Metode yang digunakan adalah metode kualitatif dan metode kuantitatif. Pembelajaran dilakukan dalam 3 kali pertemuan (6 X 45 menit) dengan materi "Mutasi". Teknik pengumpulan data dengan menggunakan angket untuk mengetahui motivasi belaja siswa. Soal pre-test dan pos-test untuk mengetahui hasil belajar siswa. Angket dan soal test diberikan sebelum dan sesudah proses pembelajaran dengan metode simulasi berbasis project based learning.

Penilaian angket motivasi belajar siswa menggunakan Skala Likert dengan ketentuan utnuk kuisioner dengan jawaban "sangat tidak setuju" (STS) diberi skor 1, "tidak setuju" (TS) skor 2, "ragu-ragu" (RR) skor 3, "setuju" (S) skor 4, dan "sangat setuju" (SS) skor 5. (https://teknikelektronika.com)

Untuk menghitung persentase hasil penilaian angket motivasi belajar setiap siswa menggunakan rumus:

$$
\begin{aligned}
& \text { Jml skor tiap siswa } \\
& \% \text { tiap siswa=--------------------------X100 } \\
& \text { Jml skor maksimal }
\end{aligned}
$$

Persentase klasikal dapat dicari dengan menghitung rata-rata dari keseluruhan siswa.

Selanjutnya untuk mengetahui kriteria terjadinya peningkatan motivasi belajar siswa sebelum dan sesudah dapat menggunakan kriteria sebagaimana tabel 1 berikut.

Tabel 1. Kriteria Motivasi Belajar Siswa

\begin{tabular}{|c|c|}
\hline Interval & Kategori \\
\hline $10 \%-40 \%$ & Sangat Rendah \\
\hline $41 \%-60 \%$ & Rendah \\
\hline $61 \%-80 \%$ & Tinggi \\
\hline $81 \%-100 \%$ & Sangat tinggi \\
\hline
\end{tabular}

(sumber: olahan peneliti, 2020)
Adapun kriteria Penilaian hasil belajar siswa berdasarkan ketercapaian kriteria ketuntasan minimal (KKM) mata pelajaran biologi kelas XII MIPA SMA Negeri 1 Moga yaitu 70, serta ketuntasan belajar secara klasikal. Untuk mengetahui terjadinya peningkatan hasil belajar siswa dapat dilihat dari selisih nilai pre-test dan nlai pos-test dengan menghitung $\mathrm{N}$-gain menggunakan rumus:

$$
\begin{gathered}
\text { Skor pos-test }- \text { Skor pre-test } \\
\text { N-gain }=---------------------------- \\
\text { Skor maksimal }- \text { skor pre-test }
\end{gathered}
$$

Dari nilai indeks $\mathrm{N}$-gain yang diperoleh diinterpretasikan untuk mengetahui taraf peningkatan hasil belajar siswa dengan menggunakan kriteria seperti pada tabel 2 berikut.

Tabel 2: Kategori N-gain peningkatan hasil belajar siswa.

\begin{tabular}{|c|c|}
\hline Koefisien & Kategori \\
\hline $0,80<\mathrm{N}$-gain $<100$ & Sangat tinggi \\
\hline $0,60<\mathrm{N}$-gain $<0,80$ & Tinggi \\
\hline $0,40<\mathrm{N}$-gain $<0,61$ & Sedang \\
\hline $0,20<\mathrm{N}$-gain $<0,40$ & Rendah \\
\hline $\mathrm{N}$-gain $<0,20$ & Sangat rebdah \\
\hline \multicolumn{2}{|c}{ (Meltzer, 2002) }
\end{tabular}

\section{HASIL}

\section{Motivasi Belajar Siswa}

Untuk mengetahui bagaimana motivasi belajar siswa sebelum dan sesudah menggunakan metode simulasi berbasis project based learning, didasarkan dari hasil analisis pada jawaban angket siswa (34 siswa) sebagaimana tabel 3 dan tabel 4 berikut. 
Tabel 3: Hasil jawaban angket siswa pada kegiatan pembelajaran secara konvensional.

\begin{tabular}{|c|c|c|c|c|c|c|c|}
\hline No & Pernyataan & STS & TS & $\mathrm{RR}$ & $\mathbf{S}$ & $\mathbf{S S}$ & Persentase \\
\hline 1 & $\begin{array}{l}\text { Pembelajaran biologi secara } \\
\text { konvensional membuat saya merasa } \\
\text { lebih berminat untuk mempelajari } \\
\text { materi tersebut. }\end{array}$ & 4 & 16 & 48 & 24 & - & $54 \%$ \\
\hline 2 & $\begin{array}{l}\text { Pembelajaran biologi secara } \\
\text { konvensional membuat saya merasa } \\
\text { tertantang untuk mempersiapkan } \\
\text { materi terlebih dahulu sebelum } \\
\text { kegiatan pembelajaran. }\end{array}$ & - & 20 & 54 & 20 & 4 & $58 \%$ \\
\hline 3 & $\begin{array}{l}\text { Dengan pembelajaran biologi secara } \\
\text { konvensional saya menjadi berperan } \\
\text { aktif selama kegiatan pembelajaran }\end{array}$ & 1 & 20 & 54 & 20 & - & $56 \%$ \\
\hline 4 & $\begin{array}{l}\text { Pembelajaran biologi secara } \\
\text { konvensional saya lakukan secara } \\
\text { bersungguh- sungguh. }\end{array}$ & 2 & 22 & 45 & 12 & 10 & $54 \%$ \\
\hline 5 & $\begin{array}{l}\text { Pembelajaran biolgi secara } \\
\text { konvensional menjadikan saya lebih } \\
\text { antusias. }\end{array}$ & 1 & 18 & 45 & 28 & 10 & $60 \%$ \\
\hline 6 & $\begin{array}{l}\text { Pembelajaran biologi secara } \\
\text { konvensional tidak membosankan. }\end{array}$ & - & 26 & 48 & 12 & 5 & $54 \%$ \\
\hline 7 & $\begin{array}{l}\text { Pembelajaran biologi secara } \\
\text { konvensional meningkatkan semangat } \\
\text { belajar. }\end{array}$ & 2 & 6 & 81 & 12 & - & $59 \%$ \\
\hline 8 & $\begin{array}{l}\text { Pembelajaran biologi secara } \\
\text { konvensional, menumbuhkan rasa } \\
\text { percaya diri. }\end{array}$ & 4 & 24 & 54 & 4 & 5 & $54 \%$ \\
\hline 9. & $\begin{array}{l}\text { Pembelajarn secara konvensional } \\
\text { meningkatkan kreatifitas. }\end{array}$ & 1 & 16 & 60 & 12 & - & $52 \%$ \\
\hline 10 & $\begin{array}{l}\text { Pembelajaran biologi secara } \\
\text { konvensional memudahkan } \\
\text { pemahaman materi yang dipelajari. }\end{array}$ & 3 & 20 & 46 & 20 & 5 & $55 \%$ \\
\hline & Persentase Rata-rata & & & & & & $55,53 \%$ \\
\hline
\end{tabular}


Tabel 4: Hasil jawaban angket siswa pada kegiatan pembelajaran dengan metode simulasi berbasis project based learning.

\begin{tabular}{|c|c|c|c|c|c|c|c|}
\hline No & Pernyataan & STS & TS & RR & $\mathbf{S}$ & SS & Persentase \\
\hline 1 & $\begin{array}{l}\text { Pembelajaran biologi konsep mutasi } \\
\text { dengan metode simulasi berbasis } \\
\text { project based learning membuat saya } \\
\text { merasa lebih berminat untuk }\end{array}$ & - & 4 & 9 & 52 & 80 & $85 \%$ \\
\hline 2 & $\begin{array}{l}\text { Pembelajaran biologi konsep mutasi } \\
\text { dengan metode simulasi berbasis } \\
\text { project based learning membuat saya } \\
\text { merasa tertantang untuk } \\
\text { mempersiapkan materi terlebih dahulu }\end{array}$ & - & - & 15 & 72 & 55 & $84 \%$ \\
\hline 3 & $\begin{array}{l}\text { Dengan pembelajaran biologi konsep } \\
\text { mutasi menggunakan metode simulasi } \\
\text { berbasis project based learning, saya } \\
\text { menjadi berperan aktif selama kegiatan } \\
\text { pembelajaran }\end{array}$ & - & - & 12 & 40 & 100 & $89 \%$ \\
\hline 4 & $\begin{array}{l}\text { Pembelajaran biologi konsep mutasi } \\
\text { dengan metode simulasi berbasis } \\
\text { project based learning saya lakukan } \\
\text { secara bersungguh- sungguh. }\end{array}$ & - & - & 9 & 92 & 40 & $83 \%$ \\
\hline 5 & $\begin{array}{l}\text { Pembelajaran biolgi konsep mutasi } \\
\text { menggunakan metode simulasi berbasis } \\
\text { project based learning menjadikan saya } \\
\text { lebih antusias. }\end{array}$ & - & 2 & 6 & 72 & 65 & $85 \%$ \\
\hline 6 & $\begin{array}{l}\text { Pembelajaran biologi konsep mutasi } \\
\text { dengan metode simulasi berbasis } \\
\text { project based learning tidak }\end{array}$ & - & - & 9 & 44 & 100 & $90 \%$ \\
\hline 7 & $\begin{array}{l}\text { Pembelajaran biologi konsep mutasi } \\
\text { dengan metode simulasi berbasis } \\
\text { project based learning meningkatkan } \\
\text { semangat belajar. }\end{array}$ & - & - & 18 & 56 & 70 & $85 \%$ \\
\hline 8 & $\begin{array}{l}\text { Pembelajaran biologi konsep mutasi } \\
\text { dengan metode simulasi berbasis } \\
\text { project based learning menumbuhkan } \\
\text { rasa percaya diri. }\end{array}$ & - & - & 12 & 64 & 70 & $86 \%$ \\
\hline 9. & $\begin{array}{l}\text { Pembelajarn biologi konsep mutasi } \\
\text { dengan metode simulasi berbasis } \\
\text { project based learning meningkatkan }\end{array}$ & - & - & - & 32 & 120 & $89 \%$ \\
\hline 10 & $\begin{array}{l}\text { Pembelajaran biologi konsep mutasi } \\
\text { dengan metode simulasi berbasis } \\
\text { project based learning memudahkan } \\
\text { pemahaman materi yang dipelajari. }\end{array}$ & - & - & 6 & 48 & 100 & $91 \%$ \\
\hline & Persentase Rata-rata & & & & & & $86,71 \%$ \\
\hline
\end{tabular}


Hasil Belajar Siswa

Untuk mengetahui terjadinya peningkatan hasil belajar siswa dapat

Tabel 5 : Hasil nilai pre-test dan pos-test siswa.

\begin{tabular}{|c|c|c|}
\hline Kategori & Nilai Pre-Test & Nilai Pos-Test \\
\hline Jumlah & 2130 & 2790 \\
\hline Nilai Terkecil & 50,00 & 60,00 \\
\hline Nilai Terbesar & 80,00 & 95,00 \\
\hline Rata-rata & 62,65 & 82,06 \\
\hline
\end{tabular}

\section{PEMBAHASAN}

\section{Pembahasan Motivasi Belajar Siswa.}

Dari hasil analisis jawaban angket motivasi belajar siswa sebelum dan dilihat dari data nilai pre-test dan postest seperti tabel 5 berikut.

Grafik 1: Perbandingan motivasi belajar siswa.

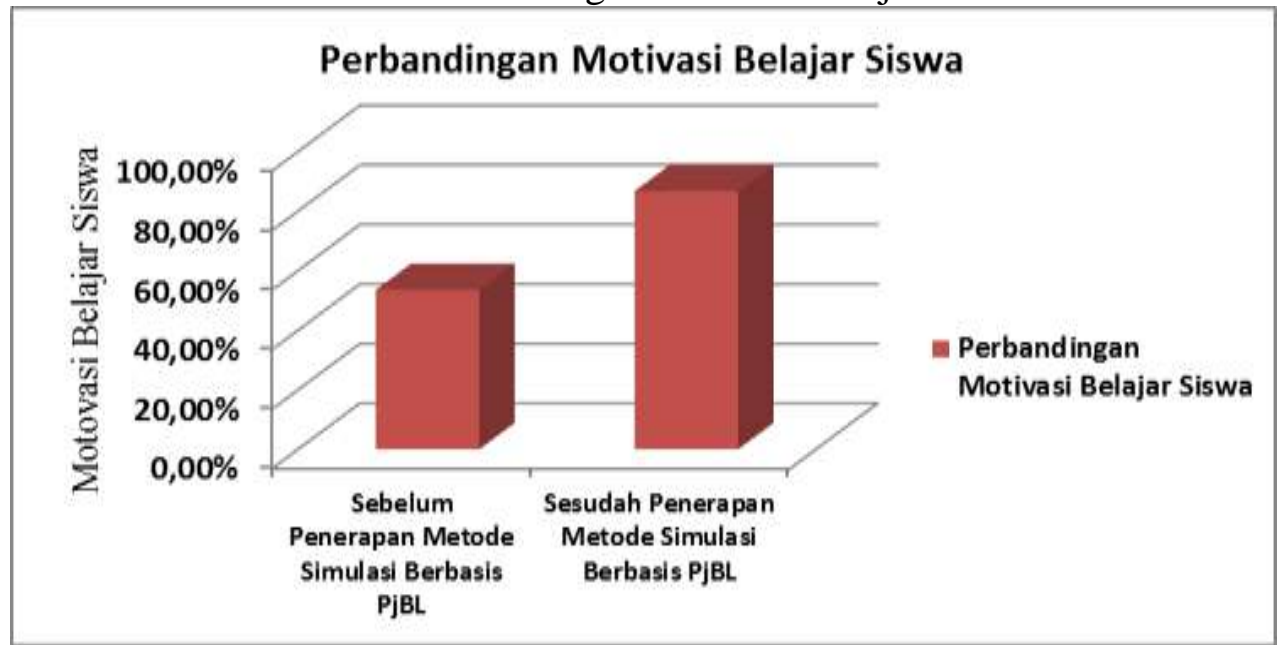

Dari grafik di atas dapat diketahui bahwa hasil persentase rata-rata skor motivasi belajar siswa sebelum pembelajaran menggunakan metode simulasi berbasis project based learning adalah 53,53\% dengan kategori rendah. Sedangkan persentase rata-rata skor motivasi belajar siswa setelah pembelajaran menggunakan metode simulasi berbasis project based learning adalah 86,71\% dalam kategori motivasi "sangat tinggi". Peningkatan motivasi belajar siswa disebabkan mereka tertarik untuk mengikuti pembelajaran melalui simulasi langsung dimana seluruh siswa terlibat secara aktif dan memiliki peran masingmasing selama kegiatan pembelajaran.

Terjadinya peningkatan motivasi belajar sebenarnya mulai terlihat ketika guru menjelaskan kegiatan pembelajaran sesudah penggunaan metode simulasi berbasis project based learning pada konsep mutasi dapat dideskripsikan menggunakan grafik 1 berikut: 
9.1\% menjadi $30.3 \%$ dan dalam kriteria sangat tinggi.

\section{Pembahasan Hasil Belajar Siswa}

Dari hasil analisis penghitungan hasil pre-test dan post-test menggunakan program microsoft excel dapat diketahui terjadi peningkatan nilai pada pos-test. Terjadinya peningkatan hasil belajar dapat dilihat dari nilai rata-rata pre-test sebesar 62,65 meningkat rata-ratanya menjadi 82,06 pada saat pos-test. Selanjutnya dengan menggunakan rumus $\mathrm{N}$-gain dapat diketahui selisih nilai pretest dan post test dengan koifisien $=0,6$, termasuk kategori "tinggi". Disini dapat diketahui bahwa peningkatan hasil belajar siswa yang "tinggi" pada konsep mutasi dengan metode simulasi berbasis project based learning berkorelasi dengan terjadinya peningkatan hasil belajar mereka. Hal ini terjadi karena seluruh siswa berperan aktif mengambil bagian dalam simulasi dan dapat melihat hasil belajarnya secara berulang-ulang melaui project yang mereka buat berupa video pembelajaran.Untuk menggambarkan terjadinya peningkatan nilai dapat kita perhatikan grafik 2 berikut.

Grafik 2: Perbandingan hasil belajar siswa

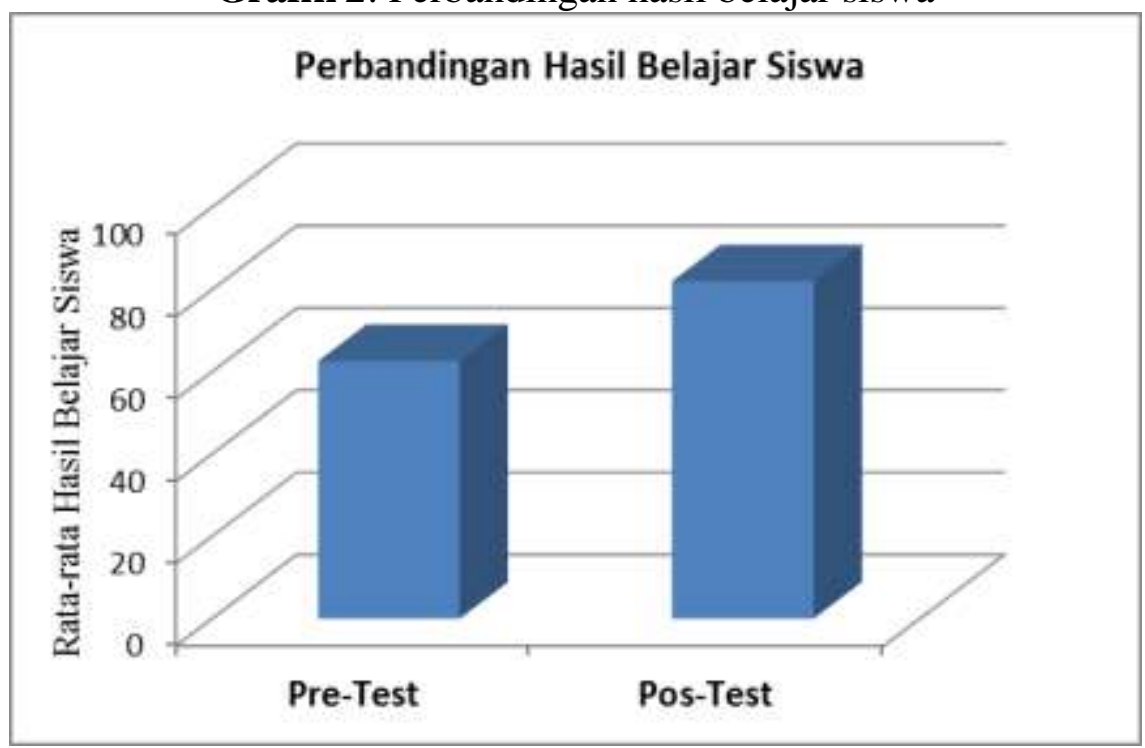

Dari 34 siswa terdapat 31 siswa yang mencapai KKM artinya 91,18\% siswa mengalami ketuntasan belajarnya, hanya 3 orang yang memperoleh hasil kurang dari KKM. Dengan ketuntasan belajar klasikal 91,18\%, menunjukkan bahwa pembelajaran dengan metode simulasi berbasis project based learning ternyata sangat membantu daya ingat mereka terhadap materi sudah dipelajarinya.

Hasil belajar siswa mengalami peningkatan sejalan dengan hasil penelitian Inyasiska (2015), pembelajaran project based learning dapat mempengaruhi motivasi belajar siswa lebih tinggi 14\%, kreativitas siswa meningkat $31,1 \%$, kemampuan berpikir kritis meningkat 34\% dan melalui pembelajaran proyek yang bersifat kontekstual, kemampuan kognitif siswa juga meningkat 28,9\% dari pada pembelajaran yang diberikan tanpa melalui proyek.

\section{IMPLIKASI}

Dari hasil peneltian dan pembahasan sebelumnya dapat di tarik kesimpulan sebagai berikut::

1. Penerapan metode simulasi berbasis project based learning dapat meningkatkan motovasi belajar siswa. Hal ini dapat ditinujkkan dengan adanya peningkatan persentase ratarata skor angket motivasi sebelum dan sesudah pembelajaran $(53,53 \%$ kategori rendah menjadi $86,71 \%$ kategori sangat tinggi) 
2. Penerapan metode simulasi berbasis project based learning dapat meningkatkan hasil belajar siswa. Peningkatan hasil belajar siswa dapat dilihat dengan terjadinya kenaikan hasil belajar siswa dimana rata- rata capaian hasil belajar siswa sebelum kegiatan pembelajaran menggunakan metode simulasi berbasis project based learning (pre-test) hanya 62,65, setelah pembelajaran menggunakan metode simulasi berbasis project based learning (pos-test) adalah 82,06 diatas KKM 70 yang ditentukan. Dengan ketuntasan klasikal sebesar 91,18\%.

3.Melalui metode simulasi berbasis project based learning ada dua project yang dapat dihasilkan, yaitu project skenario materi simulasi, dan dokumen video pembelajaran mutasi.

4. Meskipun pembelajaran masih sedikit mengalami kendala terutama pengaturan waktu, dan kesiapan properti, kegiatan tetap dapat berjalan sesuai rencana.

\section{REFERENSI}

Cahyani, R. (2017). Pengaruh penerapan model pembelajaran kreatifproduktif terhadap pencapaian kompetensi dasar pada pembelajaran biologi kelas X lintas minat SMA Negeri 1 Sokaraja Tahun Ajaran 2016/2017, Universitas Muhammadiyah Purwokerto.

Djamarah, S. B., \& Zein, A. (2010). Strategi Belajar Mengajar. Jakarta: Rineka Cipta.

Hariyanti, T. (2011). Penerapan metode simulasi untuk meningkatkan aktivitas dan hasil belajar siswa pada pokok bahasan ekosistem di kelas X Madrasah Aliyah Muhammadiyah 1 Malang, University of Muhammadiyah Malang. https://www.hipwee.com/narasi/pembela jaran-yang-menarik-dan menyenangkan/

https://silabus.org/pengertian-metode/

https://teknikelektronika.com/pengertianskala-likert-likert-scalemenggunakan-skala-likert/

Hutasuhut, S. (2010). "Implementasi pembelajaran berbasis proyek (project-based Learning) untuk meningkatkan motivasi dan hasil belajar Mata kuliah pengantar ekonomi pembangunan Pada jurusan manajemen fe unimed." Jurnal Pendidikan Ekonomi Dan Bisnis 2(01).

Inyasiska, D., et al. (2017). "Pengaruh project based learning terhadap motivasi belajar, kreativitas, kemampuan berpikir kritis, dan kemampuan kognitif siswa pada pembelajaran biologi." Jurnal Pendidikan Biologi 7(1): 9-21.

Jon, E. (2018). "Pengembangan Perangkat Pembelajaran Terpadu Berorientasi Kreatif Produktif pada materi Biologi Sel dan Reproduksi Sel untuk SMA." Menara Ilmu 12(80).

Mahanal, S., et al. (2010). "Pengaruh Pembelajaran Project Based Learning (PjBL) pada Materi Ekosistem terhadap Sikap dan Hasil Belajar Siswa SMAN 2 Malang." BIOEDUKASI (Jurnal Pendidikan Biologi) 1(1).

Mulyani, S. (2017). "Penggunaan Media Kartu (Flash Card) dalam Meningkatkan Hasil Belajar Konsep Mutasi bagi Peserta Didik Kelas XII." Jurnal Profesi Keguruan 3(2): 143-148. 
Oya, R. N. and C. A. Budiningsih (2014). "Peningkatkan motivasi dan hasil belajar Bahasa Indonesia menggunakan model pembelajaran kreatif dan produktif." Jurnal Prima Edukasia 2(1): 116-126.

Sudjana, N. (2009). Dasar-dasar Proses Belajar Mengajar. Bandung: Sinar Baru Algensindo.

Ulfa, K. (2017). Penerapan strategi pembelajaran ppdp untuk meningkatkan penguasaan konsep dan kemampuan berpikir tingkat tinggi siswa SMA pada materi fotosintesis, Universitas Pendidikan Indonesia.

Wahyuni, D. and K. Baroroh (2012). "Penerapan Metode Pembelajaran Simulasi Untuk Meningkatkan Aktivitas Dan Prestasi Belajar Ekonomika Mikro." Jurnal Ekonomi dan Pendidikan. 